\title{
Spatial and Temporal Distribution of Plant Parasitic Nematodes in Eastern Vidarbha Zone, India
}

\author{
N. V. Lavhe ${ }^{1 *}$, D. B.Undirwade ${ }^{1}$, Nandini Gokte-Narkhedkar ${ }^{2}$ and A. V. Kolhe ${ }^{1}$ \\ ${ }^{1}$ Department of Entomology, College of Agriculture, Nagpur, Dr. PDKV, Akola, India \\ ${ }^{2}$ ICAR-CICR, Nagpur, India \\ *Corresponding author
}

\begin{tabular}{|c|}
\hline Keywords \\
\hline $\begin{array}{l}\text { Plant parasitic } \\
\text { nematodes, Genera, } \\
\text { Absolute frequency, } \\
\text { Relative frequency, } \\
\text { Absolute density, } \\
\text { Relative density }\end{array}$ \\
\hline Article Info \\
\hline $\begin{array}{l}\text { Accepted: } \\
\text { 04 November } 2019 \\
\text { Available Online: } \\
10 \text { December } 2019\end{array}$ \\
\hline
\end{tabular}

A B S T R A C T
A survey was conducted for Eastern Vidarbha region of Maharashtra state which aimed to provide a map of the status of plant parasitic nematodes in the region. More than 266 Soil samples were collected from 44 talukas of 4 districts covering 19 crop systems. About 16 genera of plant parasitic nematodes were recorded from the samples. Predominant ones recorded in all the districts were Rotylenchulus, Hoplolaimus, Helicotylenchus, Pratylenchus, Meloidogyne, Tylenchulus and Tylenchorhynchus waere prominently recorded in all the districts. Whereas genera Hemicycliophora, Psilenchus, Radopholus, Ditylenchus, Xiphinema and Criconema were recorded sporadically. All these nematode genera showed higher prominence values while Shannon index and Shannon evenness index indicated uniform trend of richness and evenness in all the talukas of eastern Vidarbha region.

\section{Introduction}

There are numerous estimates of the economic importance of nematodes in crop production on a world wide and individual country basis, but precise estimation of losses is lacking. Systematic studies on prevalence and distribution have not been done for Vidarbha region of Maharashtra state. Nematodes are of major importance to agricultural crops as environment is congineal for nematode population build up. Importance of nematodes as disease causing entities have often been overlooked. Symptoms caused due to nematode infestation are non-specific and mistaken for nutritional deficiency ones. Nematode damage to crops is dependent on nematode density in soil. Damage caused by nematodes gets manifested only when nematode populations cross threshold level of economic damage. Therefore, Studies on prevalence of plant parasistic nematode is 
important to estimate role of nematodes in agricultural crops.

Vidarbha is one of the five regions of Maharashtra state comprising of eastern, western and central vidarbha. Vidarbha having eleven districts is divided into two subdivisions i.e. Amravati and Nagpur subdivisions.

About 58\% of forest cover of Maharashtra State is in Vidarbha region. Forest percentage is much more in eastern part i.e. in Bhandara \& Gondia (51.07\%), Chandrapur (46.4\%), Gadchiroli (94.49\%).

The percentage forest cover is $38.27 \%$ as against the national policy of $33 \%$. The overall level of ground water development in the region is only $34 \%$.

In different regions of the Maharashtra state the nematodes reported in 1978,1984 and 1990 were root knot nematode (Meloidogyne incognita) and reniform nematode (Rotylenchulus reniformis) on cotton, pulses and fruit crops; the citrus nematode (Tylenchulus semipenitrans) on sweet orange and mandarins and burrowing nematode (Radopholus similis) on banana.

Whereas, the harmful nematodes identified are cyst nematodes i.e. Heterodera zea on maize, Heterodera cajani on pigeonpea and Heterodera sorghi on sorghum, respectively (Anonymous, 2010).

\section{Materials and Methods}

The survey was conducted for 04 districts of Eastern Vidarbha zone of Nagpur division. The soil samples were collected from each taluka and evaluated for presence of plant parasitic nematodes. This study will provide a map of the status of plant parasitic nematodes in the region.

\section{Experimental details}

The soil samples were collected from different cropping systems at different locations in the Vidrabha region during the respective seasons and analysed at Nematology Laboratory, Central Institute for Cotton Research, Nagpur.

\section{Collection of soil sample for plant parasitic nematodes}

Representative soil samples were collected from different agroecosystems i.e. pigeon pea, paddy, vegetables, sugarcane, forest trees, pomegranate, beetlevine, chilli, turmeric, banana etc.

The sample was taken from the rhizosphere area of the crop. The soil sample were taken from depth of approximately $0-15$ or $30 \mathrm{~cm}$ using a hand shovel/small kudal.

For extraction of nematodes from soil sieving and decanting technique developed by Dr. N.A.Cobb (1918) was followed using the material i.e. Two plastic pan, 5 sieves (18, $60,100,200,350 \mathrm{mesh}), 250 \mathrm{ml}$ beakers, aluminium wire mesh molded in a shape which can be placed on Petri-plate, facial tissue paper, petriplates.

Extraction of Plant parasitic nematodes was done by Cobb's Sieving and Decanting Technique. Nematodes were identified based on morphological characters visible under stereobinocular microscope. Identification was confirmed under compound microscope. Statistical analysis was done by analysing population of nematodes using the following indices and factors.

Shannon Evenness Index $(E)=H / L n S$

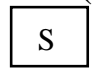

Shannon Diversity $\operatorname{Index}(H)=-\sum$ pi $\ln$ pi

$i=$ 
Where,

P- The proportion $(\mathrm{n} / \mathrm{N})$ of individuals of one particular species found (n) divided by the total number of individuals found(N).

Ln- Natural log. $\sum$ - Sum of the calculations sNumber of species

The population densities of nematode species in the samples were calculated using the formulae (Norton, 1978).

Absolute frequency

No. of samples containing a species

No. of samples collected

Relative frequency

Frequency of a species $\mathrm{x} 100$

Sum of frequencies of all spp.

Relative Density

No. of individuals of a species in a sample

Total of all individuals

in a sample

Absolute Density

No. of individuals of

a species in a sample

----------------- x100

Volume or mass or units

of the sample

Prominence value

Absolute density X

$\sqrt{ }$ Absolute frequency

100

Morphological Characterization was done by preparing slides by picking individual nematodes (Juveniles or adults) singly and placed it on glass slide, and comparing the characters observed with the characters recorded in the Identification keys for agriculturally important plant parasitic nematodes developed by CIMMYT, Mexico and others, and from books.

\section{Results and Discussion}

The soil samples were collected from each taluka and evaluated for presence of plant parasitic nematodes. This study will provide a map of the status of plant parasitic nematodes in the region

\section{Experimental findings}

The investigations were carried out to study the prevalence and distribution of plant parasitic nematodes in Eastern Vidarbha region.

In view of the importance of the plant parasitic nematodes causing losses to the different agricultural crops, the occurrence of different plant parasitic nematodes in Eastern Vidarbha region were assessed by survey and collection of soil samples and analysing it in the laboratory.

\section{Prevalence and distribution (Spatial and temporal) of plant parasitic nematodes in Eastern Vidarbha region}

All the 04 districts of EVZ were surveyed and the 266 samples were evaluated for the presence of plant parasitic nematodes. About 16 genera of plant parasitic nematodes from 04 districts were reported.

The genera Rotylenchulus, Hoplolaimus, Helicotylenchus, Aphelenchoides, Pratylenchus, Meloidogyne, Tylenchulus, Paratylenchus, Hirschmanniella and Tylenchorynchus was prominently recorded in all the districts. Whereas genera 
Hemicyclophora, Psilenchus, Radophilus, Ditylenchus, Xiphinema and Criconema were recorded in 1 district each. The population recorded was analysed for 05 factors and 2 indices which represent the intensity, prevalence and the distribution of the population in the region (Table 1-4).

\section{Absolute and Relative frequency of Plant parasitic nematodes}

Gondia district recorded absolute and relative frequency Helicotylenchus, Hoplolaimus, Pratylenchus, Tylenchulus, Meloidogyne, Hirschmanniella, Paratylenchus, Rotylenchulus was most prominent in almost all districts followed by Aphelenchoides and Tylenchorynchus. Gadchiroli district recorded absolute and relative frequency highest for genera Helicotylenchus followed by Hoplolaimus, Pratylenchus Tylenchulus, Rotylenchus, Aphelenchoide, Hirschmanniella, Meloidogyne, Ditylenchu, s Paratylenchus and Radophilus.

Absolute and relative frequency recorded for Bhandara district was highest for genera Helicotylenchus followed by Tylenchulus, Pratylenchus, Hoplolaimus, Rotylenchus, Hirschmanniella, Aphelenchoides, Meloidogyne, Paratylenchus, Tylenchorynchus and Xiphinema. In Chandrapur district the absolute and relative frequency recorded highest for genera Tylenchulus followed by Helicotylenchus, Pratylenchus, Rotylenchus, Hoplolaimus, Aphelenchoides, Hirschmanniella, Meloidogyne, Paratylenchus, Cricone, Hemicyclophora, Psilenchus and Tylenchorynchus.

Free living nematodes i.e. Aporcelaimus, Longidorus, Acrobelus, AporcelaimellusDorylaimida, Mononchus, Cephaobus, Acrobolaidus, Rhabditonema, Dorylaimus, were recorded in varying numbers in all the districts of Eastern vidarbha region.

\section{Absolute and relative density of plant parasitic nematodes}

Gondia district recorded absolute and relative density highest for genera Pratylenchus followed by Helicotylenchus Hoplolaimus, Tylenchulus, Meloidogyne, Hirschmanniella, Rotylenchulus, Paratylenchus, Aphelenchoides and Tylenchorynchus.

Absolute and relative density recorded for Gadchiroli district was highest for genera Helicotylenchus followed by Hoplolaimus, Tylenchulus, Hirschmanniella Aphelenchoide, Rotylenchulus, Pratylenchus Meloidogyne, Tylenchorynchus, Ditylenchus and Radophilus.

Bhandara district has recorded highest absolute and relative density for genera Helicotylenchus followed by Pratylenchus, Tylenchulus, Hoplolaimus, Hirschmanniella, Rotylenchulus, Meloidogyne, Aphelenchoides, Paratylenchus, Tylenchorynchus and Xiphinema. In Chandrapur district the absolute and relative density recorded highest for genera Tylenchulus followed by Pratylenchus, Helicotylenchus, Rotylenchulus, Hoplolaimus, Aphelenchoides, Hirschmanniella, Meloidogyne, Paratylenchus, Cricone, Hemicyclorapha, Psilechus and Tylenchorynchus.

Prominence value of Plant parasitic nematodes in districts of Eastern Vidarbha zone

Gondia district recorded prominence value highest for genera Helicotylenchus followed by Pratylenchus, Hoplolaimus, Tylenchulus, Meloidogyne, Hirschmanniella, Rotylenchulus, Paratylenchus, Aphelenchoides and Tylenchorynchus. 
Table.1 Absolute \& Relative frequency percent of Plant parasitic nematodes in different districts of Eastern Vidarbha region

\begin{tabular}{|c|c|c|c|c|c|c|c|c|c|}
\hline \multirow{2}{*}{$\begin{array}{c}\text { S. } \\
\text { No. }\end{array}$} & \multirow[t]{2}{*}{ Genera } & \multicolumn{2}{|c|}{ Gondia } & \multicolumn{2}{|c|}{ Gadchiroli } & \multicolumn{2}{|c|}{ Bhandara } & \multicolumn{2}{|c|}{ Chandrapur } \\
\hline & & $\begin{array}{l}\text { Abs. } \\
\text { Freq. }\end{array}$ & Rel. freq & $\begin{array}{l}\text { Abs. } \\
\text { Freq. }\end{array}$ & Rel. freq & $\begin{array}{l}\text { Abs. } \\
\text { Freq. }\end{array}$ & Rel. freq & $\begin{array}{l}\text { Abs. } \\
\text { Freq. }\end{array}$ & $\begin{array}{l}\text { Rel. } \\
\text { freq. }\end{array}$ \\
\hline 1 & Helicotylenchus & 75.00 & 13.49 & 74.47 & 12.57 & 100 & 18.09 & 61.25 & 11.75 \\
\hline 2 & Hoplolaimus & 71.15 & 12.80 & 63.83 & 10.77 & 58.82 & 10.64 & 53.75 & 10.31 \\
\hline 3 & Pratylenchus & 71.15 & 12.80 & 61.70 & 10.41 & 67.65 & 12.23 & 61.25 & 11.75 \\
\hline 4 & Tylenchulus & 69.25 & 12.46 & 55.32 & 9.34 & 70.59 & 12.77 & 75.00 & 14.39 \\
\hline 5 & Meloidogyne & 42.31 & 7.61 & 30.85 & 5.21 & 17.65 & 3.19 & 18.75 & 3.60 \\
\hline 6 & Hirschmanniella & 38.46 & 6.92 & 48.94 & 8.26 & 50.00 & 9.04 & 22.50 & 4.32 \\
\hline 7 & Paratylenchus & 26.92 & 4.84 & 6.38 & 1.08 & 8.82 & 1.60 & 11.25 & 2.16 \\
\hline 8 & Rotylenchus & 25.00 & 4.50 & 50.00 & 8.44 & 50.00 & 9.04 & 56.25 & 10.79 \\
\hline 9 & Aphelenchoides & 23.08 & 4.15 & 48.94 & 8.26 & 17.65 & 3.19 & 38.75 & 7.43 \\
\hline 10 & Tylenchorynchus & 13.46 & 12.46 & 24.47 & 4.13 & 70.59 & 1.60 & 1.25 & 0.24 \\
\hline 11 & Ditylenchus & 0 & 0 & 24.47 & 0.54 & 0 & 0 & 00 & 0 \\
\hline 12 & Radophilus & 0 & 0 & 3.19 & 0 & 0 & 0 & 0 & 0 \\
\hline 13 & Xiphinema & 0 & 0 & 0 & 0 & 2.94 & 0.53 & 0 & 0 \\
\hline 14 & Cricone & 0 & 0 & 0 & 0 & 0 & 0 & 11.25 & 2.16 \\
\hline 15 & Hemicyclophora & 0 & 0 & 0 & 0 & 0 & 0 & 5.00 & 0.96 \\
\hline 16 & Psilenchus & 0 & 0 & 0 & 0 & 0 & 0 & 5.00 & 0.96 \\
\hline 17 & Freeliving & 100 & 17.99 & 100 & 16.88 & 100 & 18.09 & 100 & 19.18 \\
\hline
\end{tabular}

Table.2 Absolute \& Relative density percent of Plant parasitic nematodes in different districts of Eastern Vidarbha region

\begin{tabular}{|c|c|c|c|c|c|c|c|c|c|}
\hline \multirow{2}{*}{$\begin{array}{c}\text { S. } \\
\text { No. }\end{array}$} & Genera & \multicolumn{2}{|c|}{ Gondia } & \multicolumn{2}{c|}{ Gadchiroli } & \multicolumn{2}{|c|}{ Bhandara } & \multicolumn{2}{c|}{ Chandrapur } \\
\cline { 3 - 10 } & & $\begin{array}{c}\text { Abs. } \\
\text { den. }\end{array}$ & $\begin{array}{l}\text { Rel. } \\
\text { den. }\end{array}$ & $\begin{array}{l}\text { Abs. } \\
\text { den. }\end{array}$ & $\begin{array}{l}\text { Rel. } \\
\text { den. }\end{array}$ & $\begin{array}{l}\text { Abs. } \\
\text { den. }\end{array}$ & $\begin{array}{l}\text { Rel. } \\
\text { den. }\end{array}$ & $\begin{array}{l}\text { Abs. } \\
\text { den. }\end{array}$ & $\begin{array}{c}\text { Rel. } \\
\text { den. }\end{array}$ \\
\hline $\mathbf{1}$ & Helicotylenchus & 1.67 & 12.86 & 1.75 & 12.54 & 2.15 & 17.02 & 1.42 & 11.09 \\
\hline $\mathbf{2}$ & Hoplolaimus & 1.56 & 12.01 & 1.49 & 10.64 & 1.32 & 10.48 & 1.30 & 10.13 \\
\hline $\mathbf{3}$ & Pratylenchus & 1.67 & 12.88 & 0.92 & 6.56 & 1.49 & 11.80 & 1.45 & 11.30 \\
\hline $\mathbf{4}$ & Tylenchulus & 1.40 & 10.78 & 1.32 & 9.41 & 1.45 & 11.48 & 1.69 & 13.21 \\
\hline $\mathbf{5}$ & Meloidogyne & 1.08 & 8.32 & 0.81 & 5.81 & 0.43 & 3.38 & 0.48 & 3.75 \\
\hline $\mathbf{6}$ & Hirschmanniella & 1.02 & 7.89 & 1.31 & 9.38 & 1.19 & 9.46 & 0.58 & 4.51 \\
\hline $\mathbf{7}$ & Paratylenchus & 0.59 & 4.57 & 0.15 & 1.06 & 0.18 & 1.43 & 0.26 & 2.04 \\
\hline $\mathbf{8}$ & Rotylenchus & 0.63 & 4.88 & 1.22 & 8.72 & 1.18 & 9.39 & 1.44 & 11.22 \\
\hline $\mathbf{9}$ & Aphelenchoides & 0.57 & 4.36 & 1.23 & 8.78 & 0.35 & 2.77 & 0.94 & 7.33 \\
\hline $\mathbf{1 0}$ & Tylenchorynchus & 0.23 & 2.25 & 0.55 & 3.94 & 0.17 & 1.37 & 0.03 & 0.21 \\
\hline $\mathbf{1 1}$ & Ditylenchus & 0 & 0 & 0.59 & 4.23 & 0 & 0 & 0 & 0 \\
\hline $\mathbf{1 2}$ & Radophilus & 0 & 0 & 0.08 & 0.56 & 0 & 0 & 0 & 0 \\
\hline $\mathbf{1 3}$ & Xiphinema & 0 & 0 & 0 & 0 & 0.07 & 0.53 & 0 & 0 \\
\hline $\mathbf{1 4}$ & Cricone & 0 & 0 & 0 & 0 & 0 & 0 & 0.25 & 1.98 \\
\hline $\mathbf{1 5}$ & Hemicyclophora & 0 & 0 & 0 & 0 & 0 & 0 & 0.18 & 1.38 \\
\hline $\mathbf{1 6}$ & Psilenchus & 0 & 0 & 0 & 0 & 0 & 0 & 0.11 & 0.87 \\
\hline $\mathbf{1 7}$ & Freeliving & 2.49 & 19.18 & 2.57 & 18.38 & 2.53 & 20.89 & 2.69 & 20.98 \\
\hline
\end{tabular}


Table.3 Prominence value of Plant parasitic nematodes in different districts of Eastern Vidarbha region

\begin{tabular}{|c|c|c|c|c|c|}
\hline S.No. & Genera & Gondia & Gadchiroli & Bhandara & Chandrapur \\
\hline $\mathbf{1}$ & Helicotylenchus & 0.14 & 0.15 & 0.21 & 0.11 \\
\hline $\mathbf{2}$ & Hoplolaimus & 0.13 & 0.12 & 0.10 & 0.10 \\
\hline $\mathbf{3}$ & Pratylenchus & 0.14 & 0.07 & 0.12 & 0.11 \\
\hline $\mathbf{4}$ & Tylenchulus & 0.12 & 0.10 & 0.12 & 0.15 \\
\hline $\mathbf{5}$ & Meloidogyne & 0.07 & 0.015 & 0.02 & 0.02 \\
\hline $\mathbf{6}$ & Hirschmanniella & 0.06 & 0.09 & 0.08 & 0.03 \\
\hline $\mathbf{7}$ & Paratylenchus & 0.03 & 0 & 0.01 & 0.01 \\
\hline $\mathbf{8}$ & Rotylenchus & 0.03 & 0.09 & 0.08 & 0.11 \\
\hline $\mathbf{9}$ & Aphelenchoides & 0.03 & 0.09 & 0.01 & 0.06 \\
\hline $\mathbf{1 0}$ & Tylenchorynchus & 0.01 & 0.03 & 0.01 & 0 \\
\hline $\mathbf{1 1}$ & Ditylenchus & 0 & 0.03 & 0 & 0 \\
\hline $\mathbf{1 2}$ & Radophilus & 0 & 0 & 0 & 0 \\
\hline $\mathbf{1 3}$ & Xiphinema & 0 & 0 & 0 & 0 \\
\hline $\mathbf{1 4}$ & Cricone & 0 & 0 & 0 & 0.01 \\
\hline $\mathbf{1 5}$ & Hemicyclophora & 0 & 0 & 0 & 0 \\
\hline $\mathbf{1 6}$ & Psilenchus & 0 & 0 & 0 & 0 \\
\hline $\mathbf{1 7}$ & Freeliving & 0.25 & 0.25 & 0.26 & 0.27 \\
\hline
\end{tabular}

Table.4 Population indices of nematode population in different districts of Vidarbha region

\begin{tabular}{|c|c|c|c|}
\hline S. & District & Shannon Diversity Index & Shannon Evenness Index \\
No. & Gondia & 2.26 & 0.94 \\
\hline $\mathbf{1}$ & Gadchiroli & 2.36 & 0.90 \\
\hline $\mathbf{2}$ & Bhandara & 2.17 & 0.85 \\
\hline $\mathbf{3}$ & Chandrapur & 2.29 & 0.87 \\
\hline $\mathbf{4}$ & & \\
\hline
\end{tabular}

Prominence value recorded for Gadchiroli district was highest for genera Helicotylenchus followed by Hoplolaimus, Tylenchulus, Hirschmanniella Aphelenchoide, Rotylenchulus, Pratylenchus, Meloidogyne, Ditylenchus, Tylenchorynchus, Paratylenchus and Radophilus.

Bhandara district has recorded highest prominence value for genera Helicotylenchus followed by Tylenchulus Pratylenchus, Hoplolaimus, Rotylenchulus,
Hirschmanniella,

Aphelenchoides,

Tylenchorynchus and Xiphinema.

Meloidogyne, Paratylenchus,

In Chandrapur district the prominence value recorded highest for genera Tylenchulus followed by Pratylenchus, Helicotylenchus, Rotylenchulus, Hoplolaimus, Aphelenchoides, Hirschmanniella, Meloidogyne, Paratylenchus, Hemicyclophora, Psilenchus and Tylenchorynchus. 


\section{Shannon diversity index}

Shannon index ranges in the range of 1.5 to 3.5 and rarely it reaches 4.0 which indicates the Shannon index increases as both the richness and the evenness of the community increase.

Shannon index recorded for Gadchiroli is 2.36 followed by, Chandrapur (2.28), Gondia (2.25) and Bhandara (2.17), respectively which indicates that all the districts show a similar trend of richness of nematode genera. (Table 4).

\section{Shannon evenness index (SEI)}

Species evenness ranges from zero to one, with zero signifying no evenness and one, a complete evenness. Shannon evenness index recorded highest in Gondia (0.94) followed by Gadchiroli (0.89), Chandrapur (0.87) and Bhandara (0.84) respectively. This indicates that the SEI for all district shows evenness of population of plant parasitic nematode genera in the region. This indicates that the SEI for all district shows evenness of population of plant parasitic nematode generas in the region.

In the studies entitled "Prevalence and distribution of Plant Parasitic nematodes in Eastern Vidarbha region" survey of 04 districts with 44 talukas shows prevalence of about 16 genera of plant parasitic nematodes and about 6-10 genera of free living nematodes.

The prominently occurring generas whose population was prominently high were identified as Rotylenchulus, Meloidogyne, Hoplolaimus, Pratylenchus, Helicotylechus, Tylenchulus, Tylenchus etc. About 16 crop systems were sampled and it was noticed that almost all the crop systems were infested with at least 4-5 genera of plant parasitic nematodes. This also indicates the likely to be increase towards the damage threshold in future.

\section{References}

Anonymous. 2011. Land Resources Atlas Vidarbha region. National Bureau of Soil Survey and Land Use Planning (NBSS\&LUP). NBSS\&LUP Publ.147. Pp-143.

Annonymous.2012. All India Co-ordinated Research project on plant parasitic nematodes at Department of Entomology, Mahatma Phule Krishi Vidyapeeth, Rahuri.

Bhosle B.B., Sehgal Mukesh, Puri S.N. and Suvasishdas 2004. Prevalence of phytophagous nematodes in rhizosphere of okra (Abelmoschus esculentus L. Moench) in parbhani district, Maharashtra, India. Indian Journal of Nematology2004, Vol. 34(1): 56-59.

Deshmukh, Swati., Sunita Borde and Vishnu Barote. 2016. Prevalence of citrus nematodes in different localities around Aurangabad city, dirstict Aurangabad (M.S.), India. Trends in Life sciences. Volume- 5 Issue- 2 (2016): 2319-5037.

Gokte-Narkhedkar, N., Mukewar, P.M. and Mayee, C.D. 2004. Plant parasitic nematodes of cotton- Farmer's hidden enemy. Technical bulletin no.27, Central Institute for Cotton Research, Nagpur, 30P.

Kavitha and Vanita Das. 2015. Characterization of Plant-Parasitic Nematode Communities Associated With Brinjal Crops in the Nagole Area of Rangareddy District, Hyderabad, Telangana, India (2011-2012). Volume 5 Issue 5, May 2016. Int. J. of Science and Research (IJSR). Pp. 2292-2297.

Kumar and Das. 2019. Diversity and community analysis of plant parasitic 
nematodes associated with citrus at citrus research station, Tinsukia, Assam. Journal of Entomology and Zoology Studies 2019; 7(3): 187-189

Nilambika, K. Sumangala, M.S. Kulkarni, K. Balaji and R.W. Anuradha. 2018. Locating Hotspots and Identification of Plant Parasitic Nematode Associated With Chrysanthemum in Karnataka, India. Int.J.Curr.Microbiol.App.Sci (2018) 7(2): 2990-2994.

Sahu R., P. Chandra and A.N. Poddar. 2011. Community analysis of plant parasitic nematodes prevalent in vegetable crops in district Durg of Chattisgarh, India.
Res. J. of Parasitology 6(2): 83-89. 2011.

Sharma.S.B. and Y.L. Nene. 2012. Spatial and Temporal distribution of Plant parasitic nematodes of Pigeon pea in Alfisols and Vertisols. Nematropica. Vol. 22, No. 1, 1992. Pp: 13-20.

Srivastava, D.S., Mukesh Sehgal, Ajay Kumar, Savita Verma, B.K. Dwivedi And S.P. Singh. 2012. Incidence of Root-Knot Nematode Associated with Okra in District Allahabad, Uttar Pradesh, India. Indian Journal of Nematology. Vol. 42, No. 1, pp. 38-41, June, 2012.

\section{How to cite this article:}

Lavhe, N. V., D. B. Undirwade, Nandini Gokte-Narkhedkar and Kolhe, A. V. 2019. Spatial and Temporal Distribution of Plant Parasitic Nematodes in Eastern Vidarbha Zone. Int.J.Curr.Microbiol.App.Sci. 8(12): 134-141. doi: https://doi.org/10.20546/ijcmas.2019.812.021 